\title{
Transparent exopolymer particles (TEP) in the deep ocean: full-depth distribution patterns and contribution to the organic carbon pool
}

\author{
Yosuke Yamada ${ }^{16, *}$, Taichi Yokokawa ${ }^{2}$, Mario Uchimiya ${ }^{1,3,4}$, Shigeto Nishino ${ }^{5}$, \\ Hideki Fukuda ${ }^{1}$, Hiroshi Ogawa ${ }^{1}$, Toshi Nagata ${ }^{1}$
}

\footnotetext{
${ }^{1}$ Atmosphere and Ocean Research Institute, The University of Tokyo, 5-1-5, Kashiwanoha, Kashiwa-shi, Chiba 277-8564, Japan ${ }^{2}$ Research and Development Center for Marine Biosciences, Japan Agency for Marine-Earth Science and Technology (JAMSTEC), Yokosuka 237-0061, Japan

${ }^{3}$ RIKEN Center for Sustainable Resource Science, 1-7-22 Suehiro-cho, Tsurumi-ku, Yokohama, Kanagawa 230-0045, Japan

${ }^{4}$ National Institute of Polar Research, 10-3, Midori-cho, Tachikawa-shi, Tokyo 190-8518, Japan

${ }^{5}$ Institute of Arctic Climate and Environment Research, Japan Agency for Marine-Earth Science and Technology (JAMSTEC), Yokosuka 237-0061, Japan
}

${ }^{6}$ Present address: Scripps Institution of Oceanography, Marine Biology Research Division, University of California San Diego, La Jolla, California 92093, USA

\begin{abstract}
Transparent exopolymer particles (TEP) play important roles in marine biogeochemical cycles. However, limited data are available regarding the TEP distribution in meso- and bathypelagic oceans. We examined the full depth distributions of TEP in the slope region of the western Arctic Ocean, and subtropical and equatorial regions of the Pacific Ocean. Chlorophyll a concentrations in the euphotic layer were similar (range: $0.1-1 \mu \mathrm{g} \mathrm{l}^{-1}$ ) in these 2 regions. TEP concentrations were 1.3-5.4 times higher (depending on depth) in the Arctic Ocean than in the Pacific Ocean. In the Arctic Ocean, TEP concentrations decreased with depth and were positively correlated with particulate organic carbon (POC) and prokaryotic parameters (abundance and production). In contrast, in the Pacific Ocean, TEP were distributed uniformly with depth and were uncoupled from POC and prokaryotic parameters. The estimated amount of carbon associated with TEP (TEP-C) exceeded that of POC in the mesopelagic layer of both regions (the TEP$\mathrm{C}$ concentrations were 2-3 times higher than the concentrations of $\mathrm{POC}$ ) and in the bathypelagic layer of the Pacific Ocean (the TEP-C concentrations were 6 times higher than the concentrations of POC). Our results suggest that TEP are a dynamic and large component of the organic carbon pool in the ocean interior, influenced by vertical transport, in situ prokaryotic production, and the self-assembly of polymeric precursors.
\end{abstract}

KEY WORDS: Transparent exopolymer particles - TEP - Mesopelagic ocean · Bathypelagic ocean $\cdot$ Carbon cycle $\cdot$ Prokaryote

\section{INTRODUCTION}

Transparent exopolymer particles (TEP), with an approximate size range of $0.4-100 \mu \mathrm{m}$ (Passow 2002, Mari et al. 2017), are a significant or even dominant component of particulate organic carbon (POC) in

\footnotetext{
${ }^{*}$ Corresponding author: yoyamada@ucsd.edu
}

the ocean (Malpezzi et al. 2013, Annane et al. 2015, Yamada et al. 2015). They are thought to be produced by phytoplankton (Engel \& Passow 2001, Passow 2002) and bacteria (Stoderegger \& Herndl 1999, Sugimoto et al. 2007, Ortega-Retuerta et al. 2010) in marine environments, playing a variety of roles in

() The authors 2017. Open Access under Creative Commons by Attribution Licence. Use, distribution and reproduction are unrestricted. Authors and original publication must be credited. 
biogeochemical cycles. These roles include enhancement of large aggregate formation, which strengthens the vertical transport of organic carbon (biological carbon pump) (Passow \& Carlson 2012, Jackson \& Burd 2015), and promotion of surface microlayer development, which affects ocean-atmosphere gas exchange (Wurl et al. 2011, Galgani et al. 2016). They also provide microhabitats for microbes to thrive in environmental conditions that are distinct from those in the surrounding bulk seawater (Azam \& Long 2001, Simon et al. 2002). However, our current knowledge of TEP distribution and dynamics is mostly based on information obtained in the upper oceans (Passow 2002, Orellana \& Leck 2014, Mari et al. 2017). Only a few studies have investigated TEP distribution in the deep ocean (Bar-Zeev et al. 2011, Wurl et al. 2011, Cisternas-Novoa et al. 2015, Busch et al. 2017). In the subtropical North Pacific (maximum depth, $4580 \mathrm{~m}$ ), TEP were found throughout the water column with concentrations that varied little over depth (Cisternas-Novoa et al. 2015). Similarly, in the eastern Pacific and Arctic Oceans, TEP were found in layers deeper than $2000 \mathrm{~m}$ (Wurl et al. 2011). In the Mediterranean Sea, the TEP concentration was higher in deep waters $(300-1000 \mathrm{~m})$ than in the subsurface chlorophyll maximum layer, where most TEP were associated with prokaryotic cells (Bar-Zeev et al. 2011). A recent study conducted in the Arctic Fram Strait also revealed that TEP in meso- and bathypelagic waters were colonized by prokaryotes, with densities (cell abundance per unit area of TEP) similar to those in upper waters (Busch et al. 2017). This evidence suggests that TEP are potentially a significant component of the POC pool and can provide organic carbon substrates for microbial consumption in deep waters. However, it has proven difficult to test these hypotheses due to the lack of data regarding the contribution of TEP to the organic carbon inventory and fluxes in the deep sea. Furthermore, our understanding of the geographic variability of TEP abundance in deep oceanic realms is severely limited. This paucity of data represents a major gap in our understanding of biogeochemical processes in meso- and bathypelagic layers, where large quantities of organic carbon are remineralized and transformed to affect global ocean carbon cycles and the Earth's climate (Nagata et al. 2010, Passow \& Carlson 2012, Hansell \& Carlson 2014).

The present study investigated the full depth distribution of TEP concentrations in 2 disparate oceanic regions of the Arctic Ocean, and the subtropical and tropical regions of the central Pacific Ocean. The data were evaluated in relation to POC concentra- tions and prokaryotic parameters (abundance and production) to infer possible regulatory mechanisms of the TEP distribution and the potential contribution of TEP to the organic carbon inventory in deep oceans.

\section{MATERIALS AND METHODS}

\section{Collection of seawater samples}

Seawater samples were collected in the slope region of the Chukchi Sea in the western Arctic Ocean onboard the RV 'Mirai' (MR12-E03, 3 September to 17 October 2012), and in the subtropical and equatorial regions of the western and central Pacific Ocean onboard the RV 'Hakuho-maru' (KH13-7, 11 to 29 December 2013). Seawater was sampled from 8 stations in the Arctic Ocean and from 3 stations in the Pacific Ocean (Fig. 1, Table 1) using 121 Niskin bottles (Model 1010X; General Oceanics) mounted on a conductivity-temperaturedepth (CTD) system (SBE11Plus; Sea-Bird Electronics). Surface water was collected using a clean bucket. Samples for the measurement of TEP as well as prokaryotic abundance and production were collected in acid-washed 2 or 11 polycarbonate bottles (Nalgene; Thermo Scientific Fisher), and samples for POC measurement were collected in acidwashed 20 or 101 polyethylene bottles. Samples were filtered within $3 \mathrm{~h}$ of collection or stored at $4^{\circ} \mathrm{C}$ and filtered within $12 \mathrm{~h}$.

\section{TEP}

Seawater samples for the determination of TEP concentration $(\mathrm{n}=3$ replicates; $500-600 \mathrm{ml}$ of seawater replicate ${ }^{-1}$ ) were filtered through $0.4 \mu \mathrm{m}$ pore size polycarbonate filters $(47 \mathrm{~mm}$ diameter; Whatman) with a vacuum of less than $150 \mathrm{mmHg}$, and stained with $0.02 \% \mathrm{w} / \mathrm{v}$ of a cationic dye, Alcian blue (8GX; Sigma-Aldrich), dissolved in $0.06 \% \mathrm{v} / \mathrm{v}$ acetic acid. The filters were frozen at $-20^{\circ} \mathrm{C}$ prior to colorimetric determination in the onshore laboratory (Passow \& Alldredge 1995). The filters were soaked in $80 \%$ sulfuric acid for $3 \mathrm{~h}$, and the absorbance at $787 \mathrm{~nm}$ was measured using a spectrophotometer (UV-1800; Shimadzu). For the measurement of filter blanks, 11 surface seawater samples were passed through a $0.4 \mu \mathrm{m}$ filter (polycarbonate filter, $47 \mathrm{~mm}$ diameter; Whatman) before use. The absorbance of the blank value was on average $0.03 \pm 0.01$ (mean 


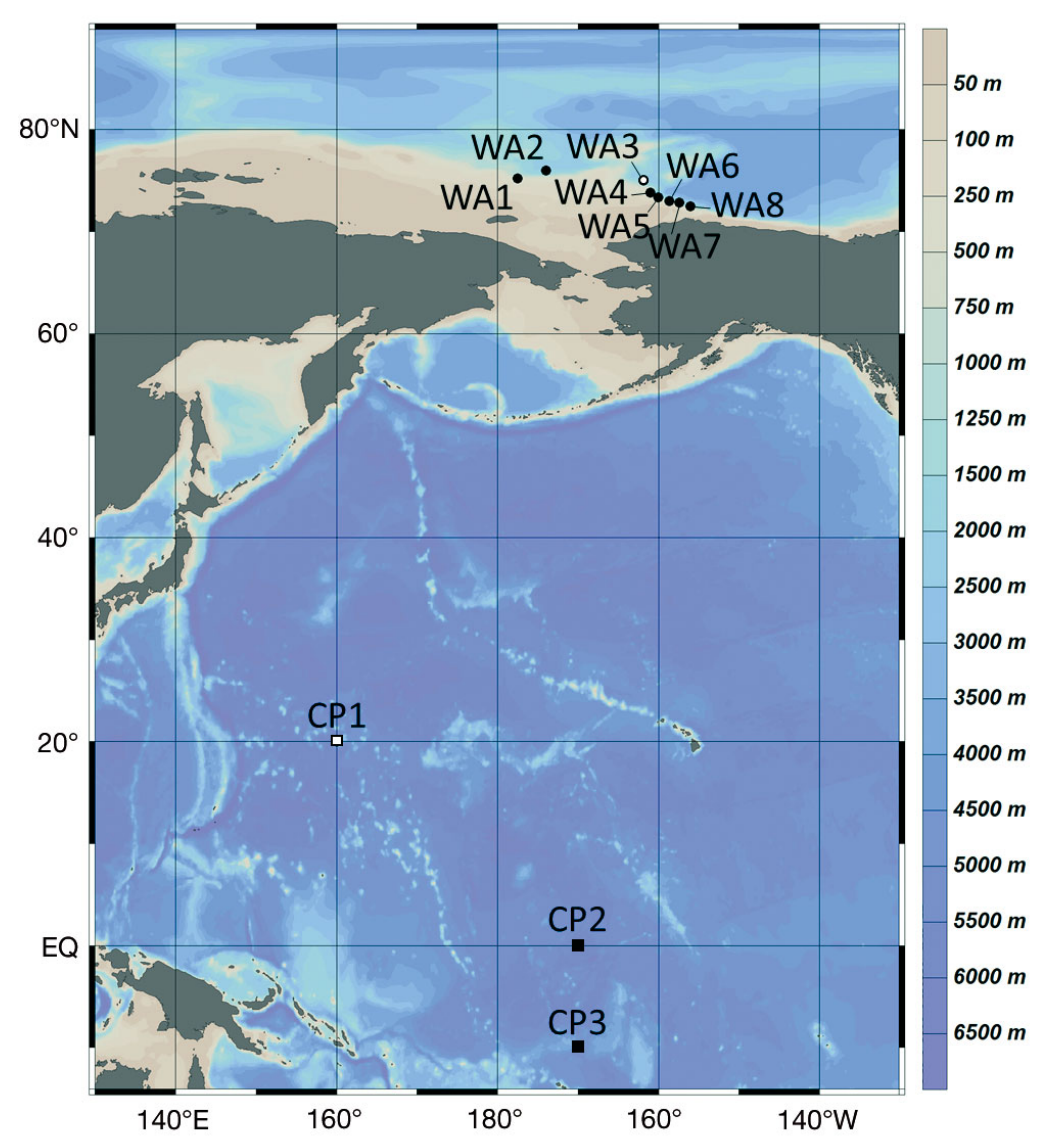

Fig. 1. Locations of the sampling stations during the Arctic cruise (MR12-E03, open circle: Stn WA3; filled circles: Stns WA1, WA2, and WA4 8) and Pacific cruise (KH13-7, open square: Stn CP1; filled squares: Stns CP2 and CP3). Open symbols indicate 'representative' stations, for which the data are presented in the main text (Figs. 2 \& 3). The map was created using Ocean Data View (http://odv.awi.de/). Details of each station are provided in Table 1 $\pm \mathrm{SD}, \mathrm{n}=9$ ) in the Arctic Ocean (a blank measurement was made at 9 selected stations, including stations in the shelf region described by Yamada et al. 2015), whereas the corresponding value was $0.06 \pm 0.01$ (mean \pm $\mathrm{SD}, \mathrm{n}=3$ ) in the Pacific Ocean (a blank measurement was conducted at every station). The mean absorbance of samples was at least 3 times higher than the blank value. For the calculation of TEP concentrations, the mean filter blank value was first subtracted from the absorbance for the samples. TEP concentration was then calculated using the calibration factor determined by the staining capacity of xanthan gum according to Passow \& Alldredge (1995) and expressed in terms of $\mu \mathrm{g}$ xanthan gum equivalent

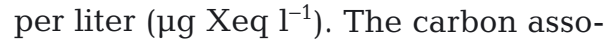
ciated with TEP (TEP-C) was estimated using the lowest (most conservative) conversion factor $(0.51 \mu \mathrm{g} \mathrm{C}$ $[\mu \mathrm{g} \mathrm{Xeq}]^{-1}$ ) reported by Engel \& Passow (2001), which was also used by Jennings et al. (2017). Our TEP-C estimates have uncertainty inherent to the use of this conversion factor derived from phytoplankton (Engel \& Passow 2001) and must be interpreted with caution (see 'Discussion').

Table 1. Locations and oceanographic features of the sampling stations deployed during the MR12-E03 and KH13-7 cruises. PAR: photosynthetically active radiation; ND: no data

\begin{tabular}{|c|c|c|c|c|c|c|c|c|c|}
\hline $\begin{array}{l}\text { Station } \\
\text { code }\end{array}$ & $\begin{array}{l}\text { Latitude } \\
\qquad\left({ }^{\circ} \mathrm{N}\right)\end{array}$ & $\begin{array}{c}\text { Longitude } \\
\left({ }^{\circ} \mathrm{E}\right)\end{array}$ & $\begin{array}{l}\text { Bottom } \\
\text { depth } \\
(\mathrm{m})\end{array}$ & $\begin{array}{c}\text { Depth of } \\
1 \% \text { PAR } \\
\text { (m) }\end{array}$ & $\begin{array}{l}\text { Water } \\
\text { temp. } \\
\left({ }^{\circ} \mathrm{C}\right)^{\mathrm{a}}\end{array}$ & $\begin{array}{c}\text { Chl a } \\
\left(\mu \mathrm{g} \mathrm{l}^{-1}\right)^{\mathrm{a}}\end{array}$ & $\begin{array}{l}\text { Nitrate } \\
(\mu \mathrm{M})^{\mathrm{a}}\end{array}$ & $\begin{array}{l}\text { Phos- } \\
\text { phate } \\
(\mu M)^{a}\end{array}$ & $\begin{array}{c}\text { Sampling } \\
\text { date } \\
\text { (mm/dd/yyyy) }\end{array}$ \\
\hline \multicolumn{10}{|c|}{ Arctic (MR12-E03) } \\
\hline WA1 & 75.2 & 182.5 & 721 & 58 & $-1.6-0.0$ & $0.16-1.19$ & $0.06-10.02$ & $0.60-1.60$ & 09/19/2012 \\
\hline WA2 & 76.0 & 186.0 & 2137 & ND & ND & ND & ND & ND & $09 / 18 / 2012$ \\
\hline WA3 & 75.0 & 191.1 & 1987 & 83 & $-0.8-1.0$ & $0.14-0.43$ & $0.04-5.41$ & $0.57-1.22$ & 09/20/2012 \\
\hline WA4 & 73.8 & 199.0 & 1552 & ND & ND & ND & ND & ND & $09 / 23 / 2012$ \\
\hline WA5 & 73.3 & 200.0 & 1390 & 71 & $-0.7-2.7$ & $0.12-0.52$ & $<0.02-2.41$ & $0.58-1.04$ & $09 / 23 / 2012$ \\
\hline WA6 & 73.0 & 201.3 & 1249 & 48 & $0.6-4.1$ & $0.17-0.90$ & $<0.02-2.64$ & $0.52-1.10$ & $09 / 24 / 2012$ \\
\hline WA7 & 72.8 & 202.6 & 1008 & ND & ND & ND & ND & ND & $09 / 24 / 2012$ \\
\hline WA8 & 72.5 & 204.0 & 1896 & ND & ND & ND & ND & ND & $09 / 24 / 2012$ \\
\hline \multicolumn{10}{|c|}{ Pacific (KH13-7) } \\
\hline CP1 & 20.0 & 160.0 & 4462 & 114 & $23.2-27.7$ & $0.09-0.56$ & $<0.02-0.16$ & $<0.01-0.03$ & $12 / 15 / 2013$ \\
\hline $\mathrm{CP} 2$ & 0.0 & 190.0 & 5462 & 70 & $27.1-27.3$ & $0.36-1.36$ & $5.65-6.35$ & $0.53-0.60$ & $12 / 22 / 2013$ \\
\hline CP3 & -10.0 & 190.0 & 5033 & 109 & $25.8-30.2$ & $0.20-1.28$ & $<0.02-4.47$ & $0.16-0.52$ & $12 / 26 / 2013$ \\
\hline
\end{tabular}




\section{POC}

Seawater samples were filtered through pre-combusted $\left(450^{\circ} \mathrm{C}\right.$ for $\left.4 \mathrm{~h}\right)$ glass fiber filters $(\mathrm{GF} / \mathrm{F}$; Whatman), with a nominal pore size of $0.7 \mu \mathrm{m}$. The filters were kept frozen $\left(-20^{\circ} \mathrm{C}\right)$ until analysis in the onshore laboratory. The filters were fumed overnight with $\mathrm{HCl}$ using the vapor method (Yamamuro \& Kayanne 1995, Turnewitsch et al. 2007) to remove carbonates and then dried at $60^{\circ} \mathrm{C}$ for $24 \mathrm{~h}$. POC was quantified with an elemental analyzer (NA-1500; Fisons Instruments), using acetanilide (Thermo Electron) as a standard. The same pre-combusted $\left(450^{\circ} \mathrm{C}\right.$ for $4 \mathrm{~h}$ ) GF/F were used for the measurement of the filter blanks. The mean filter blank value was subtracted from the value obtained for the samples.

\section{Prokaryotic abundance}

For the determination of prokaryotic abundance, a $2 \mathrm{ml}$ seawater sample was collected in a sterile cryogenic vial (Nalgene) and fixed by adding $100 \mu \mathrm{l}$ of $20 \%$ glutaraldehyde (final concentration $1 \%$ ). The fixed sample was frozen in liquid nitrogen and then stored in a freezer $\left(-80^{\circ} \mathrm{C}\right)$ until analysis in the onshore laboratory. Following Yang et al. (2010), samples in the upper layers (depth $\leq 200 \mathrm{~m}$ ) were diluted 10-fold with TE buffer $\left(10 \mathrm{mmol} \mathrm{l}^{-1}\right.$ Tris- $\mathrm{HCl}, 1 \mathrm{mmol}$ $\mathrm{l}^{-1}$ EDTA, pH 8.0; Nippon Gene) in a $7 \mathrm{ml}$ sterile test tube (Becton Dickinson). Samples in the deeper layers (depth $>200 \mathrm{~m}$ ) were not diluted. After staining with SYBR Green I (final concentration of $10^{-4}$ of commercial stock; Invitrogen), reference size beads (1 $\mu \mathrm{m}$ diameter; Molecular Probes) were added. The samples were analyzed using a flow cytometer (FACSCalibur for the Arctic Ocean samples and FACSVerse for the Pacific Ocean samples; Becton Dickinson). The respective flow cytometer was equipped with a $15 \mathrm{~mW}, 488 \mathrm{~nm}$ air-cooled laser and a standard filter set. The data were analyzed using either CellQuest (for the Arctic Ocean samples) or FACSuite (for the Pacific Ocean samples) software (Becton Dickinson). Flow cytometric analyses of prokaryotic abundance in this study enumerated only free-living cells, and cells associated with particles were not counted.

\section{Prokaryotic production}

Prokaryotic production was estimated from the rate of ${ }^{3} \mathrm{H}$-leucine incorporation (Kirchman 2001). A
$1.5 \mathrm{ml}$ seawater sample was placed in a $2 \mathrm{ml}$ sterile tube, amended with $10 \mu \mathrm{l}$ of ${ }^{3} \mathrm{H}$-leucine (NET1166, specific activity 146.5 and $161 \mathrm{Ci} \mathrm{mmol}^{-1}$ in the Arctic and Pacific Oceans, respectively, final concentration $10 \mathrm{nmol} \mathrm{l}^{-1}$; PerkinElmer) and were incubated for 1-2 $\mathrm{h}$ (upper layers with depths $\leq 200 \mathrm{~m}$ ) or $24 \mathrm{~h}$ (deeper layers with depths $>200 \mathrm{~m}$ ) at in situ temperature $\left( \pm 2^{\circ} \mathrm{C}\right)$ in the dark. The incubation was stopped by adding $80 \mu \mathrm{l}$ of $100 \% \mathrm{w} / \mathrm{v}$ trichloroacetic acid (TCA), and then the sample was centrifuged at $14000 \mathrm{rpm}(20800 \times g)$ for $10 \mathrm{~min}$ (Kubota 1130 or Eppendorf 5417R). After the extraction of the precipitate with $1 \mathrm{ml}$ of $5 \%$ TCA and $1 \mathrm{ml}$ of $80 \%$ ethanol, samples were completely dried and $1 \mathrm{ml}$ of a liquid scintillation cocktail (Ultima Gold; PerkinElmer) was added to the sample. The radioactivity was measured using a liquid scintillation counter (TRI-CARB 3110TR, PerkinElmer; or Wallac 1414, Wallac Oy). Prokaryotic production was calculated using a leucine-to-carbon conversion factor of $1.55 \mathrm{~kg} \mathrm{C} \mathrm{mol}{ }^{-1}$, assuming no isotopic dilution (Simon \& Azam 1989). For each sample, 3 replicates and 1 TCA-killed control were prepared. The coefficient of variation $(\mathrm{SD} /$ mean $\times 100)$ among the triplicate samples averaged ca. $10 \%$. Owing to the small volume of the samples used for leucine incorporation rate measurements, the production estimates in this study represent free-living prokaryotes.

\section{Environmental parameters}

Salinity, temperature, and potential density $\left(\sigma_{\theta}\right)$ were determined with a conductivity, temperature, and depth (CTD) logger (SBE9Plus and SBE11Plus; SeaBird Electronics). Data obtained in the Arctic Ocean were provided by the Japan Agency for Marine-Earth Science and Technology (JAMSTEC) and were available via the JAMSTEC data website (www.godac.jamstec.go.jp/darwin/cruise/mirai/mr12 -03/e). Photosynthetically active radiation (PAR) was determined at selected stations using a quantameter (Biospherical PAR Sensor [LI-COR] in the Arctic Ocean and Hyper Profiler [Biospherical Instruments] in the Pacific Ocean) and a pyranometer (Precision spectral pyranometer; EPLAB). PAR at the surface $(0 \mathrm{~m})$ was calculated using a conversion equation: $\mathrm{PAR}=0.45 \times$ shortwave irradiance, which was measured using the pyranometer (Campbell \& Norman 1998). The chlorophyll a ( $\mathrm{chl}$ a) concentration was determined using a fluorometer (Seapoint Sensors) mounted on a CTD system. The concentrations of nutrients (nitrate and phosphate) were determined 

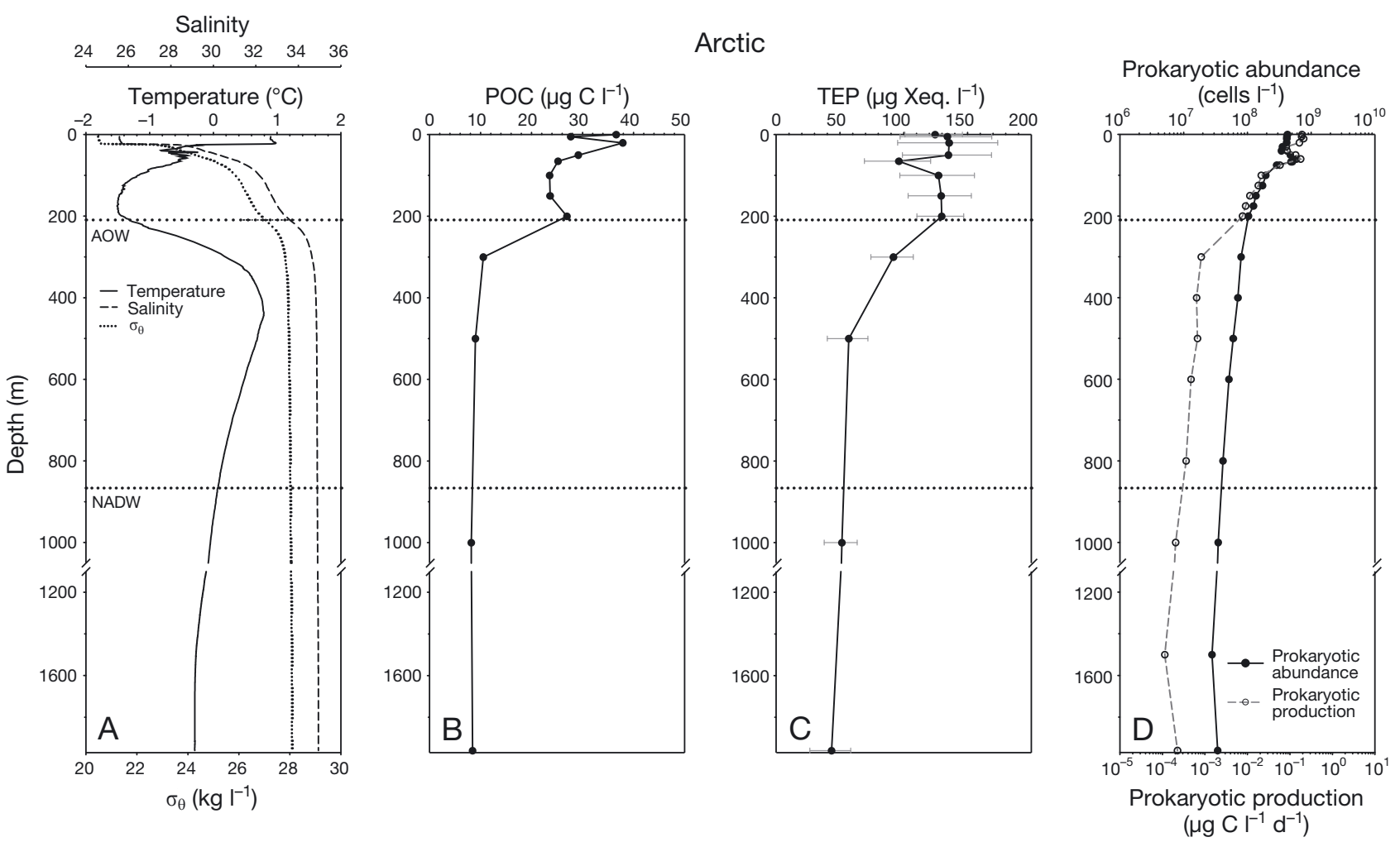

Fig. 2. Vertical distributions of (A) salinity, temperature, and potential density $\left(\sigma_{\theta}\right)$, (B) particulate organic carbon (POC), (C) transparent exopolymer particles (TEP, where Xeq: xanthan gum equivalent), and (D) prokaryotic abundance and prokaryotic production at Stn WA3 in the western Arctic Ocean. The error bars added to the TEP are standard deviations from 3 measurements. Horizontal dotted lines separate different water masses based on salinity, temperature, and density (see 'Results'; AOW: Atlantic Ocean water; NADW: North Atlantic deep water). Data for the other stations in the same region are given in Figs. S1-S7 in the Supplement at www.int-res.com/articles/suppl/m583p081_supp.pdf

spectrophotometrically using an autoanalyzer (QuA Atro, Bran+Luebbe).

Statistical calculations were performed using SigmaPlot 13.0 software (Systat Software).

\section{RESULTS}

\section{General oceanographic features of the investigated regions}

In the western Arctic Ocean, we analyzed the data collected at 8 sampling stations in the slope region of the Chukchi Sea (Fig. 1). The general oceanographic features in the study region have been described elsewhere (Yamada et al. 2015). Briefly, a strong influence of the northward flow from the Bering Strait characterizes the hydrography of the study region (Coachman et al. 1975, Springer \& McRoy 1993, Aagaard et al. 2006). Relatively warm $\left(0-1^{\circ} \mathrm{C}\right)$ Atlantic Ocean water (salinity: $34.0-34.9, \sigma_{\theta}$ : 27-28) was present in the intermediate layer (ca. 175-900 m) (Talley et al. 2011). Below a depth of ca. $900 \mathrm{~m}$, the dominant water mass was the North Atlantic Deep Water (salinity: 35, $\sigma_{\theta}$ : 28) (Schmitz 1996a, Talley et al. 2011) (Stn WA3, Fig. 2A). The other stations (i.e. WA1, WA2, and WA4-WA8) are shown in Figs. S1-S7 in the Supplement at www.int-res.com/ articles/suppl/m583p081_supp.pdf. The euphotic zone depth, defined as the depth at which PAR was $1 \%$ of the surface PAR flux, ranged from 48 to $83 \mathrm{~m}$. In the euphotic zone, the ranges of water temperature and chl a concentration were $-1.6-4.1^{\circ} \mathrm{C}$ and $0.12-1.2 \mu \mathrm{g} \mathrm{l}^{-1}$. The concentrations of nitrate and phosphate ranged from $<0.02-10.0 \mu \mathrm{M}$ and from $0.52-1.60 \mu \mathrm{M}$, respectively (Table 1 ).

In the Pacific Ocean, the sampling stations were located in the North Pacific Subtropical Gyre (Stn CP1: $20^{\circ} \mathrm{N}, 160^{\circ} \mathrm{E}$ ), the center of the equatorial upwelling (Stn $\mathrm{CP} 2$ : Equator, $170^{\circ} \mathrm{W}$ ), and the southern edge of the South Pacific Subtropical Gyre (Stn CP3: $10^{\circ} \mathrm{S}, 170^{\circ} \mathrm{W}$; Fig. 1). The vertical profiles of salinity, temperature, and potential density are given in Fig. 3A (Stn CP1) and also in Figs. S8 \& S9 in the Supplement (Stns CP2 and CP3). Low-salinity water indicated the presence of the North Pacific 

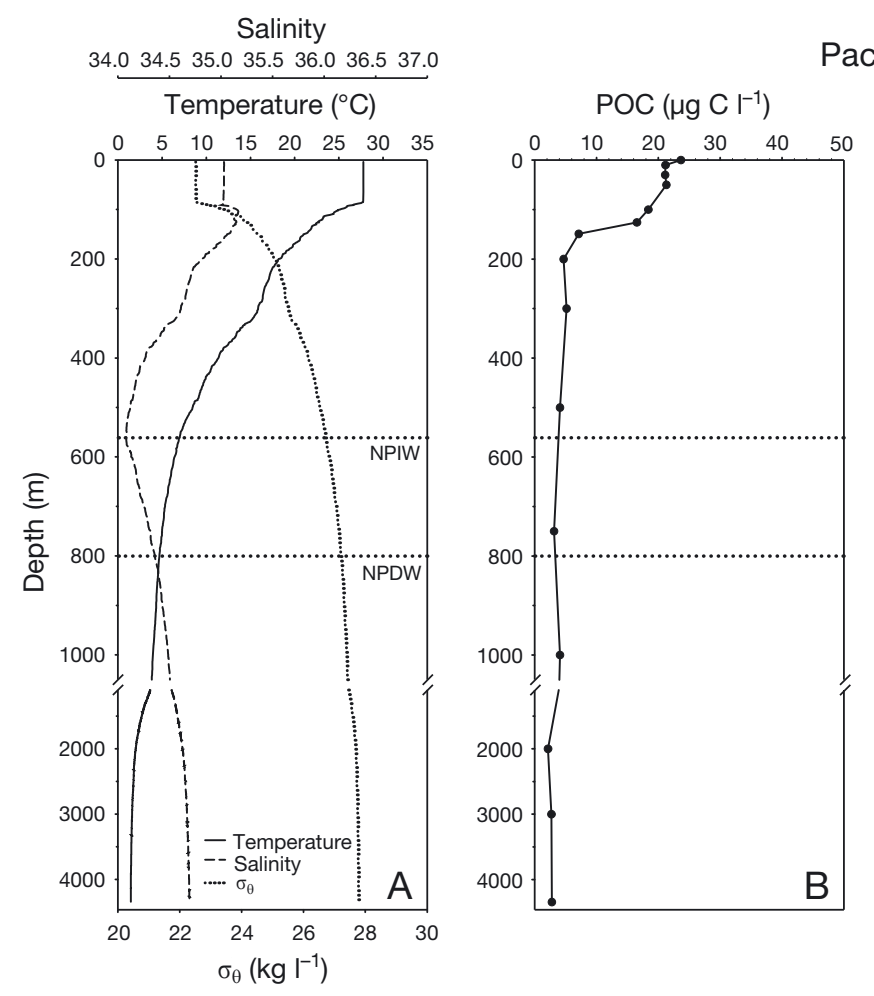

Pacific

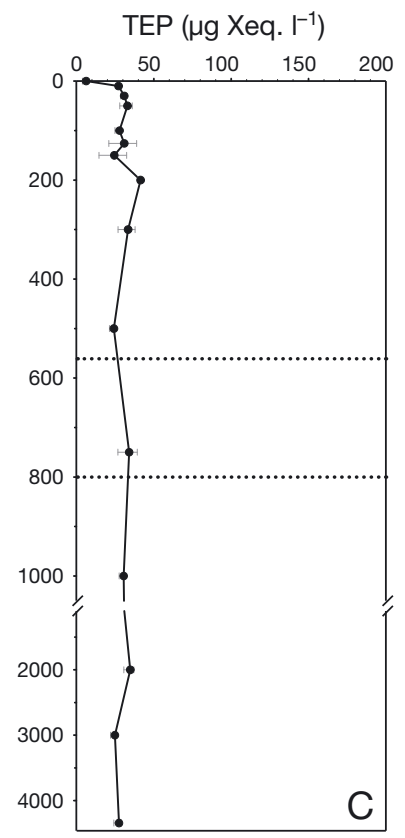

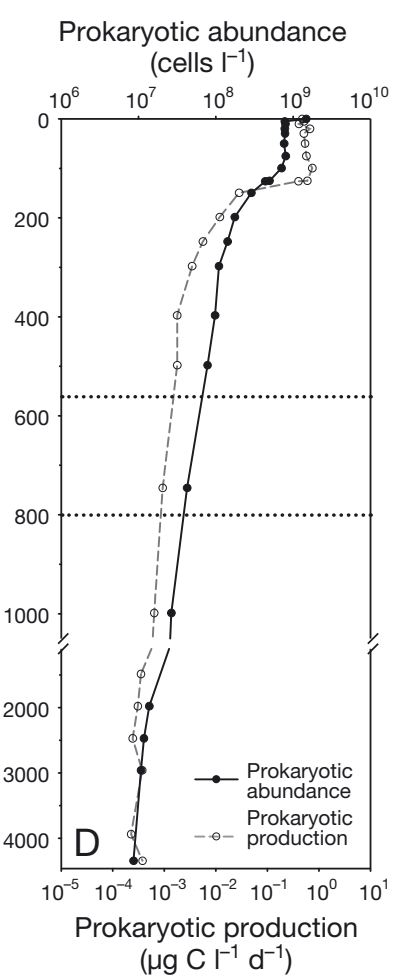

Fig. 3. As in Fig. 2, but for Stn CP1 in the Pacific Ocean. The error bars added to the TEP are standard deviations from 3 measurements. Horizotal dotted lines separate different water masses based on salinity, temperature and density (see 'Results'; NPIW: North Pacific Intermediate Water; NPDW: North Pacific Deep Water). Data for the other stations in the same region are given in Figs. S8 \& S9 in the Supplement at www.int-res.com/articles/suppl/m583p081_supp.pdf

Intermediate Water (salinity: 34.1-34.4, $\sigma_{\theta}: 26.7-$ 27.2) at a depth of 560-800 $\mathrm{m}$ at Stn CP1 (Fig. 3A) and the Antarctic Intermediate Water (salinity: 34.5 , $\left.\sigma_{\theta}: 27.2-27.5\right)$ at a depth of ca. $720-1300 \mathrm{~m}$ at Stns CP2 and CP3 (Fig. S9A) (Schmitz 1996b, Talley et al. 2011). Deep water masses were dominated by the North Pacific Deep Water $\left(\sigma_{\theta}:>27.2\right)$ at Stn CP1, and the Circumpolar Deep Water $\left(\sigma_{\theta}:>27.5\right)$ at Stns CP2 and CP3 (Schmitz 1996b, Talley et al. 2011). The euphotic zone depth ranged from 70-114 m across all stations. In the euphotic zone, the ranges of water temperature and chl $a$ were $23.2-30.2^{\circ} \mathrm{C}$ and $0.09-1.4 \mathrm{\mu g} \mathrm{l}^{-1}$. The concentrations of nitrate and phosphate were in the ranges of $<0.02-6.4$ and $<0.01-0.60 \mu \mathrm{M}$, respectively (Table 1).

\section{Vertical distribution of POC, TEP, and prokaryotic parameters}

In the Arctic, both POC and TEP concentrations were generally high in the upper layer and decreased with depth (Fig. 2B,C). The most prominent decrease in POC and TEP concentrations was generally found at depths between 200 and $300 \mathrm{~m}$. These values were relatively constant in the water column below $300 \mathrm{~m}$. The extent of the depth-dependent decrease was more pronounced for POC than for TEP. The mean TEP concentration in the upper layer

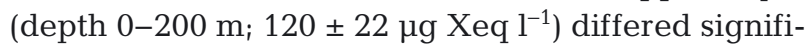
cantly ( $\mathrm{p}<0.05, t$-test) from that in the deeper layer

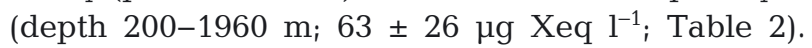

Table 2. Range of particulate organic carbon (POC) and transparent exopolymer particle (TEP) concentrations in the upper $(\leq 200 \mathrm{~m})$ and deeper $(>200 \mathrm{~m})$ layers of the Arctic and Pacific Oceans. Mean \pm SD and the number of data points (n) are given in parentheses. Xeq: xanthan gum equivalent

\begin{tabular}{|lcc|}
\hline Depth range $(\mathrm{m})$ & POC $\left(\mu \mathrm{g} \mathrm{Cl}^{-1}\right)$ & TEP $\left(\mu \mathrm{g} \mathrm{Xeq}^{-1}\right)$ \\
\hline Arctic & & \\
$0-\leq 200$ & $13-73$ & $37-130$ \\
& $(39 \pm 17, \mathrm{n}=55)$ & $(120 \pm 22, \mathrm{n}=55)$ \\
$>200-1960$ & $8.1-19$ & $39-130$ \\
& $(12 \pm 3.4, \mathrm{n}=16)$ & $(63 \pm 26, \mathrm{n}=16)$ \\
Pacific & $4.5-34$ & $5.3-40$ \\
$0-\leq 200$ & $(19 \pm 8.9, \mathrm{n}=24)$ & $(25 \pm 7.4, \mathrm{n}=24)$ \\
$>200-5367$ & $1.2-5.6$ & $14-34$ \\
& $(3.2 \pm 1.2, \mathrm{n}=21)$ & $(26 \pm 5.1, \mathrm{n}=21)$ \\
& & \\
\hline
\end{tabular}


Prokaryotic abundance and production also decreased with depth, with the most prominent decrease (by 1.2- to 210-fold) being found in the depths between 100 and $300 \mathrm{~m}$ (Fig. 2D).

In the Pacific Ocean, the vertical distribution of POC was markedly different from that of TEP (Fig. 3B,C). The POC concentration was high in the upper layer and generally decreased with depth. In contrast, the TEP concentration was relatively uniform throughout the water column. The mean TEP concentration in the upper layer (depth 0-200 m; $25 \pm 7.4 \mu \mathrm{g} \mathrm{Xeq} \mathrm{l}^{-1}$ ) did not differ significantly ( $\mathrm{p}>0.05, t$-test) from that in the deeper layer (depth 200$5367 \mathrm{~m}$; $26 \pm 5.1 \mu \mathrm{g}$ Xeq $\mathrm{l}^{-1}$; Table 2). Both prokaryotic abundance and production were relatively constant from the surface to the depth of $100 \mathrm{~m}$ and decreased sharply in the layers between 100 and $200 \mathrm{~m}$. In the meso- and bathypelagic layers, these values varied little with depth (Fig. 3D).

Fig. 4 compares the TEP concentration with other variables including POC concentration, prokaryotic abundance, and prokaryotic production. In the Arctic, TEP concentration was significantly positively correlated $(p<0.001)$ with these variables (Fig. 4A, C,E). In contrast, the correlations were insignificant $(\mathrm{p}>0.05)$ in the Pacific (Fig. 4B,D,F).

\section{Comparison of TEP-C and POC concentrations}

The TEP-C values were estimated using a conversion factor derived from phytoplankton and used to compare TEP-C with POC concentration in the upper (0-200 m), mesopelagic (200$1000 \mathrm{~m})$, and bathypelagic (10004000 m, Pacific only) layers (Table 3). The TEP-C concentration was close to the POC concentration in the upper layer (the ratio of TEP-C to POC was 0.8-1.6), whereas it exceeded the POC in the mesopelagic layer of both regions (TEP-C concentrations were 2-3 times higher than the concentrations of POC) and in the bathypelagic layer of the Pacific Ocean (TEP-C concentrations were 6 times higher than the concentrations of POC).
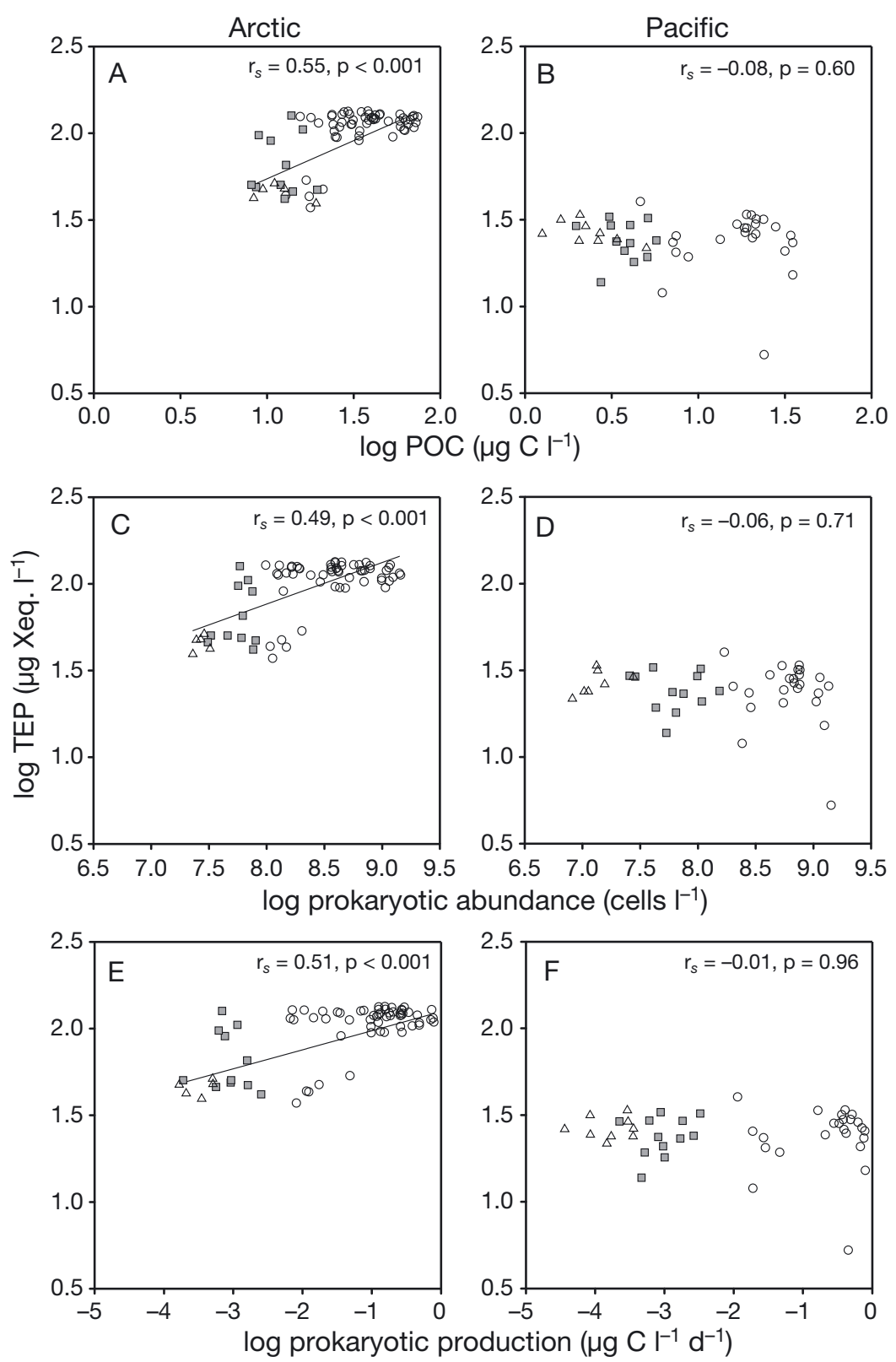

Fig. 4. Relationships between transparent exopolymer particle (TEP) concentration (where Xeq: xanthan gum equivalent) and $(A, B)$ particulate organic carbon (POC) concentration; $(C, D)$ prokaryotic abundance; and $(\mathrm{E}, \mathrm{F})$ prokaryotic production in the Arctic and Pacific Oceans, respectively. Each plot includes information on the sampling depth (open circles: $<200 \mathrm{~m}$; gray squares: $>200$ to $<1000 \mathrm{~m}$; open triangles: $>1000 \mathrm{~m})$. Spearman's rank correlation $\left(\mathrm{r}_{\mathrm{s}}\right)$ and statistical significance $(\mathrm{p})$ are given for each relationship. The lines shown with the Arctic data are least square linear regression lines. These data did not fulfill the equal variance assumption (Bartlett test, $\mathrm{p}<0.001$ ), which prevented determination of statistically valid linear model parameters (Weisberg 2013). The linear fit is provided to enable trend visualization 
Table 3. Particulate organic carbon (POC) and transparent exopolymer particle (TEP) carbon (TEP-C) concentrations ( $g$ $\mathrm{C} \mathrm{m}^{-2}$ ), and the ratio of TEP-C to POC in different depth layers of the Arctic and Pacific Oceans. Values are means \pm SD. Error propagation is considered to derive SDs for TEP-C/ POC. TEP-C was estimated by using the conversion factor of $0.51 \mu \mathrm{g} \mathrm{C}(\mu \mathrm{g} \mathrm{Xeq})^{-1}$, where Xeq: xanthan gum equivalent (Engel \& Passow 2001). The number of data points (n) are 7 and 8 at depth layers of $0-<200 \mathrm{~m}$ and $>200-1000 \mathrm{~m}$ in the Arctic, respectively, and 3 at the all depth layers in Pacific oceans. The depth-integrated values were derived using a trapezoidal assumption. The concentrations at depths of 200, 1000 , and $4000 \mathrm{~m}$ were estimated, if necessary, by either inter- or extrapolation using data collected at the adjacent depths (ND: no data)

\begin{tabular}{|lccc|}
\hline Depth range $(\mathrm{m})$ & POC & TEP-C & TEP-C/POC \\
\hline Arctic & & & \\
$0-\leq 200$ & $6.9 \pm 1.5$ & $11 \pm 0.7$ & $1.6 \pm 0.4$ \\
$>200-1000$ & $9.8 \pm 3.0$ & $23 \pm 7.9$ & $2.3 \pm 1.1$ \\
$>1000-4000$ & $\mathrm{ND}$ & $\mathrm{ND}$ & $\mathrm{ND}$ \\
Pacific & & & \\
$0-\leq 200$ & $3.2 \pm 0.2$ & $2.7 \pm 0.3$ & $0.8 \pm 0.1$ \\
$>200-1000$ & $3.2 \pm 0.1$ & $10 \pm 1.8$ & $3.2 \pm 0.6$ \\
$>1000-4000$ & $7.5 \pm 0.8$ & $41 \pm 2.6$ & $5.5 \pm 0.7$ \\
\hline
\end{tabular}

\section{DISCUSSION}

We examined the TEP distribution from the surface to bottom layers of 2 disparate regions of the Arctic and Pacific Oceans. Despite the fact that the surface chlorophyll concentrations were similarly low in both regions, TEP concentrations in deeper layers were significantly higher in the Arctic Ocean than in the Pacific Ocean. In addition, there was a difference in the vertical distribution pattern of TEP between these 2 regions. TEP concentrations tended to decrease with depth in the Arctic Ocean, whereas they were distributed uniformly with depth in the Pacific Ocean. In the following discussion, we first compare our data with values from the literature and address potential mechanisms affecting the TEP distribution, which is followed by a discussion of the contribution of TEP-C to the organic carbon inventory with consideration of methodological limitations.

\section{TEP distributions and potential mechanisms affecting them in the deep sea}

Fig. 5 compares the TEP vertical distributions observed in this study to those reported in the literature. This comparison of TEP concentrations among different studies was facilitated by the fact that these studies used the same filtration $(0.4 \mu \mathrm{m}$ pore size

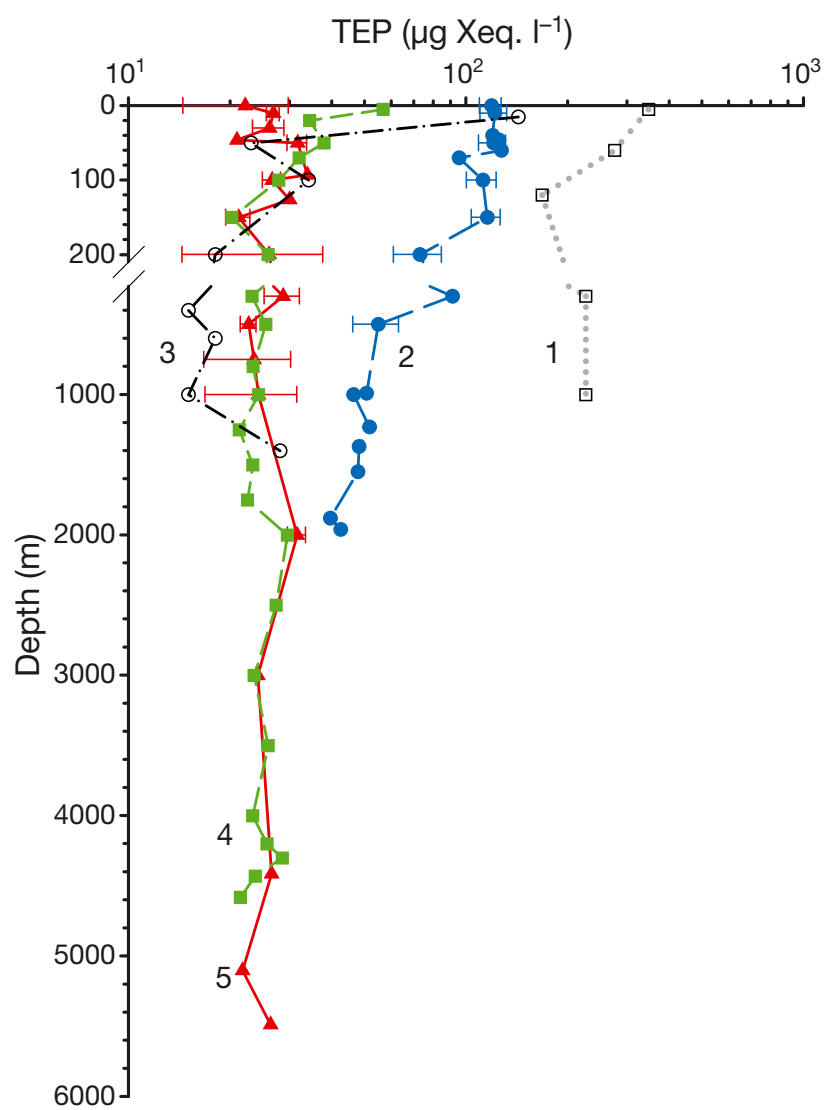

Fig. 5. Comparison of the depth profiles of the transparent exopolymer particle (TEP) concentration (where Xeq: xanthan gum equivalent) among different geographic locations. 1: Mediterranean Sea (open squares and dotted line; values are from Table 2 and Fig. 5 of Bar-Zeev et al. 2011). 2: Slope region of the western Arctic Ocean (blue circles and long dashed line; this study: means with SD [n $=6-8]$ are presented for depths at which data from multiple stations were available; plots without error bars are those from a single station). 3: Coastal eastern Pacific Ocean (open circles and dashed dotted line; values are from Fig. 6a of Passow \& Alldredge 1995). 4: Subtropical North Atlantic Ocean (green squares and short dashed line; values are from Figs. 13 \& 14 of Cisternas-Novoa et al. 2015). 5: Subtropical and equatorial regions of the Pacific Ocean (red triangles and solid line, this study: means with SD [n $=3$ ] are presented for depths at which data from 3 stations were available; the plots without error bars are those from a single station)

polycarbonate filters) and colorimetric methods (quantification of Alcian blue bound to acidic residues at $\mathrm{pH} 2.5$ ) with the use of xanthan gum as a standard. TEP concentrations displayed large regional variability (about 1 order of magnitude) in the mesopelagic layer. The TEP concentration determined in the mesopelagic water of the Arctic Ocean was the second highest value reported after a previous measurement in the Mediterranean Sea (BarZeev et al. 2011), and was characterized by a depth- 
dependent decreasing trend. TEP distributions in the Pacific Ocean (this study) and the North Atlantic Ocean (Cisternas-Novoa et al. 2015) were similar. In both regions, TEP was distributed uniformly throughout the water column, with the mean values for deeper depths $(>200 \mathrm{~m})$ being $26 \pm 5.1$ and $25 \pm$ $2.3 \mu \mathrm{g} \mathrm{Xeq} \mathrm{l}^{-1}$ in the Pacific and Atlantic Oceans, respectively. The TEP concentration in the coastal Atlantic Ocean (Passow \& Alldredge 1995) was within the range of that recorded in the Pacific and Atlantic Oceans.

The vertical transport of TEP might affect TEP distribution in deep waters. The settling velocity of individual TEP is generally considered to be low (AzetsuScott \& Passow 2004, Jennings et al. 2017). However, if they are incorporated into rapidly sinking particles through coagulation with higher-density particles (e.g. minerals, phytoplankton cells, and fecal pellets), TEP can be transferred to the deeper layers and even to the bottom (Passow 2002, Mari et al. 2017). TEP are likely to be released (dissociated) from sinking particles during their transit in the water column, a process that can be enhanced by hydrolysis of the aggregate networks by ectoenzymes produced by colonizing bacteria (Azam \& Long 2001, Kiørboe 2001). This process of TEP transfer might contribute to high TEP concentrations in deep Arctic waters. Yamada et al. (2015) found that large amounts of TEP produced on the Chukchi shelf were transported northward toward the Canada Basin through the slope region. Their results support the idea that some TEP were delivered to deeper layers of the slope region during their lateral transit from the shelf to the basin. Furthermore, the positive correlation between POC and TEP concentration (coupling of POC and TEP) in the Arctic Ocean is consistent with the model of TEP being vertically transferred to deeper layers associated with sinking POC. In addition to vertical transfer, lateral transport of TEP driven by deep water flow might also influence the TEP distribution in the deep sea, a possibility that should be examined in future studies.

In situ production of TEP might influence the TEP concentration and distribution in deep waters. One such mechanism for this is prokaryotic TEP production. In the upper oceans, several studies have found that TEP concentrations increase with increasing heterotrophic prokaryotic abundance and production (Stoderegger \& Herndl 1999, Sugimoto et al. 2007, Bar-Zeev et al. 2009, Ortega-Retuerta et al. 2010). Fig. 6 compares our results with data collected in the upper Mediterranean and the Southern Ocean (Ortega-Retuerta et al. 2009, 2010). The TEP concen-

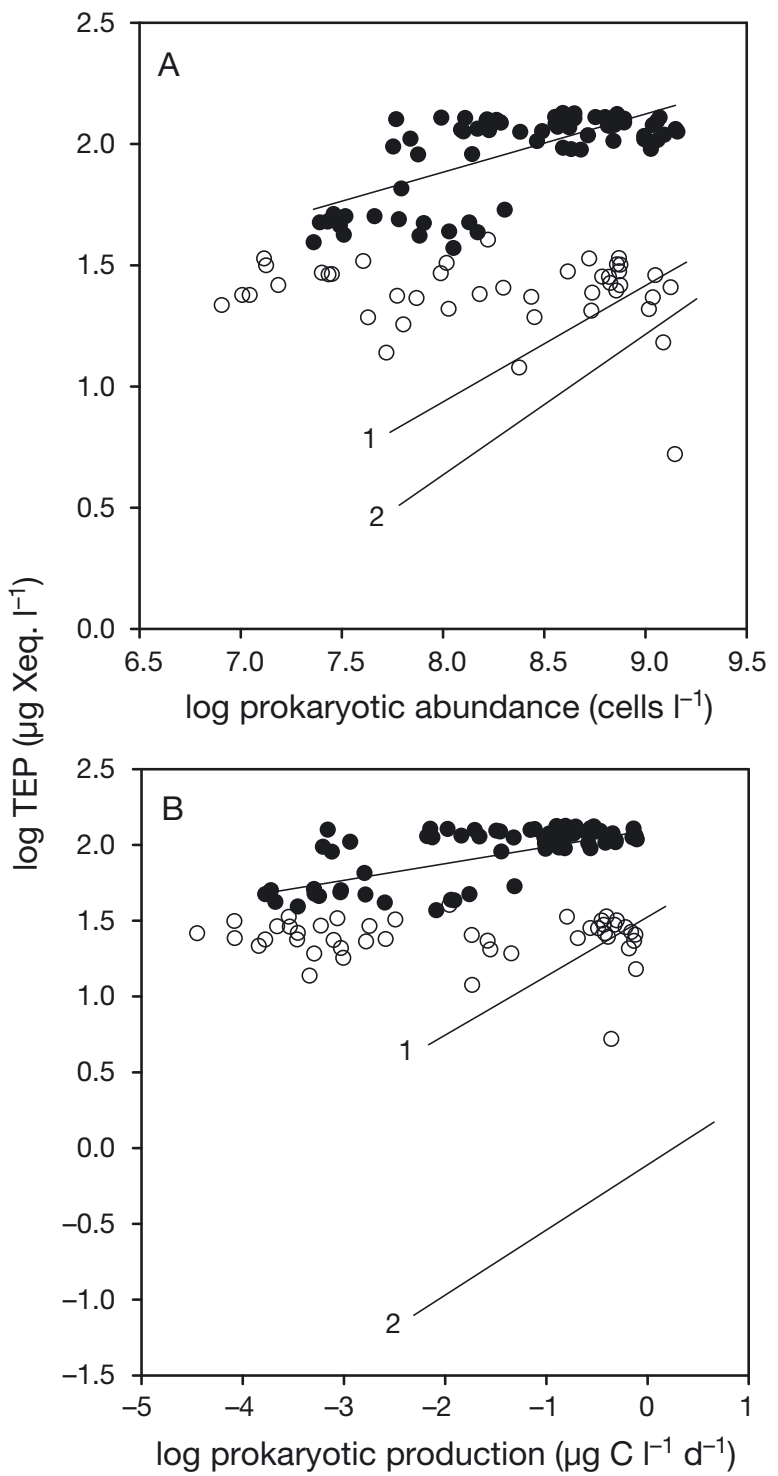

Fig. 6. Comparison of the relationship between transparent exopolymer particle (TEP) concentration (where Xeq: xanthan gum equivalent) and (A) prokaryotic abundance and (B) prokaryotic production in the Arctic Ocean (closed symbols, full depth), the Pacific Ocean (open symbols, full depth), the upper Mediterranean Sea (linear regression line from Ortega-Retuerta et al. 2010 [line 1]) and the upper Southern Ocean (linear regression line from OrtegaRetuerta et al. 2009 [line 2])

tration relative to prokaryotic abundance was generally much higher (up to 30-fold) in the Arctic and Pacific waters (including deep waters) than in the upper Mediterranean and the Southern Ocean (Fig. 6A). The TEP concentration relative to prokaryotic production in the former was also generally much higher (up to 1400-fold) than that in the latter (Fig. 6B). Largely different prokaryote-TEP relationships between the upper and deep oceans under- 
score the complexity of interactions between TEP and prokaryotes. Prokaryotes can be a source of TEP as well as consumers (decomposers) of TEP and TEP precursors (Yamada et al. 2013, Busch et al. 2017). The prokaryotic parameters-TEP relationship may be the net outcome of opposing (i.e. source and sink) prokaryotic actions on TEP abundance, which may vary depending on prokaryotic growth conditions and community composition.

Another potential in situ mechanism of TEP production is the self-assembly of polymeric precursors in seawater (Chin et al. 1998, Verdugo 2012). Gels are thought to be produced by the spontaneous assembly of polymers in seawater and may contribute to the transition of dissolved organic carbon (DOC) to POC (Chin et al. 1998, Verdugo 2012). Because high-molecular-weight DOC (HMW-DOC), presumably containing polymeric substances, is distributed throughout the deep water column (Kaiser \& Benner 2009, Benner \& Amon 2015), the self-assembly of polymeric precursors might explain the relatively uniform TEP distribution in deep Pacific (this study) and Atlantic (Cisternas-Novoa et al. 2015) waters. In their experiments conducted in the subtropical North Pacific, Ding et al. (2007) found that gels were formed by polymer self-assembly in deeper waters (500$4000 \mathrm{~m})$. Although their results suggest a potential role for polymer self-assembly in gel formation in deep waters, there is no evidence that the gels detected by their $\mathrm{Ca}^{2+}$ binding assay were TEP. Further studies are required to investigate whether marine gels containing acidic polysaccharides (TEP) spontaneously assemble in deep waters.

\section{Methodological problems with TEP-C estimation and possible contribution of TEP-C to organic carbon inventory in deep waters}

Our results of the comparison of TEP-C and POC should be interpreted with great caution due to methodological problems. First, TEP-C in our study was estimated using a conversion factor $(0.51 \mu \mathrm{g} \mathrm{C}$ $\left[\mu \mathrm{g} \mathrm{Xeq}^{-1}{ }^{-1}\right.$ ) determined from laboratory experiments using diatom cultures (Engel \& Passow 2001). In their study, POC was determined using samples collected on $0.45 \mu \mathrm{m}$ pore size filters instead of the more conventional Whatman GF/F, which have a nominal pore size of $0.7 \mu \mathrm{m}$. We used the lowest conversion factor reported by Engel \& Passow (2001), which ranged from 0.51 to $0.88 \mu \mathrm{g} \mathrm{C}(\mu \mathrm{g} \mathrm{Xeq})^{-1}$, to estimate TEP-C conservatively. The same low conversion factor has been used recently by Jennings et al. (2017) to examine the contribution of TEP-C to total organic carbon across a productivity gradient in the upper water column and surface microlayers. However, the applicability of this conversion factor in deep waters has yet to be tested. If the organic carbon yield relative to the Alcian Blue-reactive residues (sulfate and carboxyl groups) of TEP was systematically lower in the deeper than in the shallower waters, the TEP-C values estimated from the conversion factor for the shallower water (diatom-derived fresh TEP) could be too high. However, the genes coding prokaryotic enzymes that cleave sulfate residues (sulfatase) and carboxyl residues (carboxylase) are widespread and highly expressed in marine microbes (DeLong et al. 2006, Teeling et al. 2012). This suggests that the selective preservation of these reactive groups is unlikely in deep waters, although this should be verified in future studies. Second, the adsorption onto the filters of polymeric precursors that react with Alcian Blue may result in an overestimation of the TEP concentration (Passow \& Alldredge 1995). However, in our study, the TEP concentrations on the filter blanks measured by the filtration of $0.4 \mu \mathrm{m}$ filtered seawater were at least 3 times lower than those of the samples, indicating that the effect of polymer adsorption was minimal. Third, TEP-C concentrations may exceed POC concentrations because of the use of different pore size filters for the determination of TEP $(0.4 \mu \mathrm{m}$ pore size polycarbonate filter $)$ and POC ( $0.7 \mu \mathrm{m}$ pore size $\mathrm{GF} / \mathrm{F}$ filter). If large quantities of organic carbon associated with TEP passed through the GF/F filters, but were retained on the $0.4 \mu \mathrm{m}$ polycarbonate filters, this would explain the high TEP-C relative to POC. The large contribution of small TEP to total TEP concentrations has been reported in coastal waters of the North Pacific, where TEP in the size fraction of $0.2-0.6 \mu \mathrm{m}$ accounted for $67 \%$ of total TEP (Passow \& Alldredge 1995). Further studies are required to determine the size distributions of TEP and POC in deep waters. Finally, determination of TEP and POC from discrete water samples collected in Niskin bottles may suffer from biases associated with sampling and sample processing. A recent study showed that TEP concentration was underestimated by 1-13\% due to settling of TEP in the space below the spout of Niskin bottles (Suter et al. 2017). If this occurred during our sampling, we might have slightly to moderately underestimated TEP concentrations.

Although there are several potential problems associated with the estimates of TEP-C concentration, our first-order estimates indicated that TEP-C concentrations were several-fold greater than POC. 
The contribution of TEP-C to the total organic carbon inventory in deep waters could be significant. Compared with DOC and HMW-DOC values reported in the Pacific Ocean (Skoog \& Benner 1997: $2^{\circ} \mathrm{S}, 140^{\circ} \mathrm{W}$ and $12^{\circ} \mathrm{S}, 135^{\circ} \mathrm{W}$; and Kaiser \& Benner 2009: $22.75^{\circ} \mathrm{N}, 158^{\circ} \mathrm{W}$ ), concentrations of TEP-C integrated over the meso- and bathypelagic water columns accounted for only $2-3 \%$ of DOC. However, TEP-C accounted for a significant fraction $(10-14 \%)$ of HMW-DOC, suggesting that TEP-C could affect HMW-DOC measurements in deep Pacific waters. As discussed in the previous section, high TEP abundance in deep water may be related to vertical transport and in situ production of TEP (prokaryotic TEP production and the self-assembly of polymers). The relative contributions of different mechanisms in determining the TEP distribution at depth likely differ among oceanographic regions, as suggested from the markedly different vertical distribution patterns of TEP between the Arctic and the Pacific Oceans. Given the high potential contribution of TEP to the organic carbon inventory in the deep ocean, future studies should clarify the roles of TEP in key biogeochemical processes in the ocean interior, including the transition of DOC to POC, vertical and lateral transport of organic carbon, and organic carbon remineralization.

\section{CONCLUSIONS}

This study showed that the concentrations and vertical distribution of TEP in deep oceanic water columns differed between the Arctic and the Pacific Oceans. We suggest that TEP transport (possibly via the sinking of TEP aggregates and their disintegration during transit through the water column) and in situ TEP production (prokaryotic production and the self-assembly of polymeric precursors) had an influence on TEP distributions in the deep sea. Our data also suggest that TEP-C significantly contributes to the organic carbon inventory in meso- and bathypelagic layers of both oceans, underscoring the necessity for future studies to examine the hitherto understudied organic carbon fluxes mediated by TEP in deep waters. For such studies, improvement in the accuracy of TEP-C determination in deep waters is urgently needed, with a primary goal being the reduction of uncertainties associated with the TEP to TEP-C conversion. A more accurate assessment of the TEP-C dynamics in deep waters should help resolve many of the emerging questions concerning the prokaryotic lifestyle (DeLong et al. 2006, Suna- gawa et al. 2015), prokaryote-organic carbon interactions (Arrieta et al. 2015), the apparent complexity of carbon cycles (Hansell \& Carlson 2013, Follett et al. 2014), and large apparent discrepancies between organic carbon supply and microbial carbon demand (Burd et al. 2010, Nagata et al. 2010, Uchimiya et al. 2013) in deep oceanic realms.

Acknowledgements. This study was supported by Japan Society for the Promotion of Science (JSPS) KAKENHI Grant Number 15H01725 awarded to T.N. and by the Green Network of Excellence (GRENE) Arctic Climate Change Research Project. We thank the captains, officers, and crews of the RVs 'Mirai' and 'Hakuho-maru' for their support during the cruises. The staff of Marine Works Japan assisted with water sampling and data analyses during the RV 'Mirai' cruise.

\section{LITERATURE CITED}

Aagaard K, Weingartner TJ, Danielson SL, Woodgate RA, Johnson GC, Whitledge TE (2006) Some controls on flow and salinity in Bering Strait. Geophys Res Lett 33:L19602

Annane S, St-Amand L, Starr M, Pelletier E, Ferreyra GA (2015) Contribution of transparent exopolymeric particles (TEP) to estuarine particulate organic carbon pool. Mar Ecol Prog Ser 529:17-34

Arrieta JM, Mayol E, Hansman RL, Herndl GJ, Dittmar T, Duarte CM (2015) Dilution limits dissolved organic carbon utilization in the deep ocean. Science 348:331-333

Azam F, Long RA (2001) Sea snow microcosms. Nature 414: 495-498

Azetsu-Scott K, Passow U (2004) Ascending marine particles: significance of transparent exopolymer particles (TEP) in the upper ocean. Limnol Oceanogr 49:741-748

Bar-Zeev E, Berman-Frank I, Stambler N, Vázquez Domínguez E and others (2009) Transparent exopolymer particles (TEP) link phytoplankton and bacterial production in the Gulf of Aqaba. Aquat Microb Ecol 56:217-225

* Bar-Zeev E, Berman T, Rahav E, Dishon G, Herut B, Berman-Frank I (2011) Transparent exopolymer particle (TEP) dynamics in the eastern Mediterranean Sea. Mar Ecol Prog Ser 431:107-118

Benner R, Amon RM (2015) The size-reactivity continuum of major bioelements in the ocean. Annu Rev Mar Sci 7: 185-205

Burd AB, Hansell DA, Steinberg DK, Anderson TR and others (2010) Assessing the apparent imbalance between geochemical and biochemical indicators of meso- and bathypelagic biological activity: What the @\$\#! is wrong with present calculations of carbon budgets? Deep-Sea Res II 57:1557-1571

*Busch K, Endres S, Iversen MH, Michels J, Nöthig EM, Engel A (2017) Bacterial colonization and vertical distribution of marine gel particles (TEP and CSP) in the Arctic Fram Strait. Front Mar Sci 4:166

Campbell GS, Norman JM (1998) An introduction to environmental biophysics, 2nd edn. Springer Science+ Business Media, New York, NY

* Chin WC, Orellana MV, Verdugo P (1998) Spontaneous assembly of marine dissolved organic matter into polymer gels. Nature 391:568-572 
Cisternas-Novoa C, Lee C, Engel A (2015) Transparent exopolymer particles (TEP) and Coomassie stainable particles (CSP): differences between their origin and vertical distributions in the ocean. Mar Chem 175:56-71

Coachman LK, Aagaard K, Tripp RB (1975) Bering Strait: the regional physical oceanography. University of Washington Press, Seattle, WA

DeLong EF, Preston CM, Mincer T, Rich V and others (2006) Community genomics among stratified microbial assemblages in the ocean's interior. Science 311:496-503

Ding YX, Chin WC, Verdugo P (2007) Development of a fluorescence quenching assay to measure the fraction of organic carbon present in self-assembled gels in seawater. Mar Chem 106:456-462

Engel A, Passow U (2001) Carbon and nitrogen content of transparent exopolymer particles (TEP) in relation to their Alcian Blue adsorption. Mar Ecol Prog Ser 219:1-10

Follett CL, Repeta DJ, Rothman DH, Xu L, Santinelli C (2014) Hidden cycle of dissolved organic carbon in the deep ocean. Proc Natl Acad Sci USA 111:16706-16711

Galgani L, Piontek J, Engel A (2016) Biopolymers form a gelatinous microlayer at the air-sea interface when Arctic sea ice melts. Sci Rep 6:29465

Hansell DA, Carlson CA (2013) Localized refractory dissolved organic carbon sinks in the deep ocean. Global Biogeochem Cycles 27:705-710

Hansell DA, Carlson C (2014) Biogeochemistry of marine dissolved organic matter, 2nd edn. Academic Press, London

Jackson GA, Burd AB (2015) Simulating aggregate dynamics in ocean biogeochemical models. Prog Oceanogr 133: 55-65

Jennings MK, Passow U, Wozniak AS, Hansell DA (2017) Distribution of transparent exopolymer particles (TEP) across an organic carbon gradient in the western North Atlantic Ocean. Mar Chem 190:1-12

Kaiser K, Benner R (2009) Biochemical composition and size distribution of organic matter at the Pacific and Atlantic time-series stations. Mar Chem 113:63-77

Kiørboe T (2001) Formation and fate of marine snow: smallscale processes with large-scale implications. Sci Mar 65: $57-71$

Kirchman DL (2001) Measuring bacterial biomass production and growth rates from leucine incorporation in natural aquatic environments. In: Paul JH (ed) Methods in microbiology. Academic Press, London, p 227-237

Malpezzi MA, Sanford LP, Crump BC (2013) Abundance and distribution of transparent exopolymer particles in the estuarine turbidity maximum of Chesapeake Bay. Mar Ecol Prog Ser 486:23-35

Mari X, Passow U, Migon C, Burd AB, Legendre L (2017) Transparent exopolymer particles: effects on carbon cycling in the ocean. Prog Oceanogr 151:13-37

Nagata T, Tamburini C, Arístegui J, Baltar F and others (2010) Emerging concepts on microbial processes in the bathypelagic ocean-ecology, biogeochemistry, and genomics. Deep-Sea Res II 57:1519-1536

Orellana MV, Leck C (2014) Marine microgels. In: Hansell DA, Carlson C (eds) Biogeochemistry of marine dissolved organic matter, 2nd edn. Elsevier, London, p 451-480

* Ortega-Retuerta E, Reche I, Pulido-Villena E, Agustí S, Duarte CM (2009) Uncoupled distributions of transparent exopolymer particles (TEP) and dissolved carbohydrates in the Southern Ocean. Mar Chem 115: 59-65
Ortega-Retuerta E, Duarte CM, Reche I (2010) Significance of bacterial activity for the distribution and dynamics of transparent exopolymer particles in the Mediterranean sea. Microb Ecol 59:808-818

Passow U (2002) Transparent exopolymer particles (TEP) in aquatic environments. Prog Oceanogr 55:287-333

* Passow U, Alldredge AL (1995) A dye-binding assay for the spectrophotometric measurement of transparent exopolymer particles (TEP). Limnol Oceanogr 40: 1326-1335

Passow U, Carlson CA (2012) The biological pump in a high $\mathrm{CO}_{2}$ world. Mar Ecol Prog Ser 470:249-271

Schmitz JWJ (1996a) On the world ocean circulation: Vol I. Some global features/North Atlantic Circulation. Tech Rep WHOI-96-03. Woods Hole Oceanographic Institution, Woods Hole, MA

Schmitz JWJ (1996b) On the world ocean circulation: Vol II. The Pacific and Indian Oceans/a global update. Tech Rep WHOI-96-08. Woods Hole Oceanographic Institution, Woods Hole, MA

* Simon M, Azam F (1989) Protein content and protein synthesis rates of planktonic marine bacteria. Mar Ecol Prog Ser 51:201-213

Simon M, Grossart HP, Schweitzer B, Ploug H (2002) Microbial ecology of organic aggregates in aquatic ecosystems. Aquat Microb Ecol 28:175-211

* Skoog A, Benner R (1997) Aldoses in various size fractions of marine organic matter: implications for carbon cycling. Limnol Oceanogr 42:1803-1813

Springer AM, McRoy CP (1993) The paradox of pelagic food webs in the northern Bering Sea. III. Patterns of primary production. Cont Shelf Res 13:575-599

Stoderegger KE, Herndl GJ (1999) Production of exopolymer particles by marine bacterioplankton under contrasting turbulence conditions. Mar Ecol Prog Ser 189: 9-16

* Sugimoto K, Fukuda H, Baki MA, Koike I (2007) Bacterial contributions to formation of transparent exopolymer particles (TEP) and seasonal trends in coastal waters of Sagami Bay, Japan. Aquat Microb Ecol 46:31-41

* Sunagawa S, Coelho LP, Chaffron S, Kultima JR and others (2015) Ocean plankton. Structure and function of the global ocean microbiome. Science 348:1261359

Suter EA, Scranton MI, Chow S, Stinton D, Medina Faull L, Taylor GT (2017) Niskin bottle sample collection aliases microbial community composition and biogeochemical interpretation. Limnol Oceanogr 62:606-617

Talley LD, Pickard GL, Emery WJ, Swift JH (2011) Descriptive physical ocean: an introduction (6th edn). Elsevier, Oxford

Teeling H, Fuchs BM, Becher D, Klockow C and others (2012) Substrate-controlled succession of marine bacterioplankton populations induced by a phytoplankton bloom. Science 336:608-611

Turnewitsch R, Springer BM, Kiriakoulakis K, Vilas JC and others (2007) Determination of particulate organic carbon (POC) in seawater: the relative methodological importance of artificial gains and losses in two glassfiber-filter-based techniques. Mar Chem 105:208-228

* Uchimiya M, Fukuda H, Nishino S, Kikuchi T, Ogawa H, Nagata T (2013) Vertical distribution of prokaryote production and abundance in the mesopelagic and bathypelagic layers of the Canada Basin, western Arctic: implications for the mode and extent of organic carbon delivery. Deep-Sea Res I 71:103-112 
Verdugo P (2012) Marine microgels. Annu Rev Mar Sci 4: $375-400$

Weisberg S (2013) Applied linear regression, 4th edn. John Wiley \& Sons, New York, NY

Wurl O, Miller L, Vagle S (2011) Production and fate of transparent exopolymer particles in the ocean. J Geophys Res 116: $\mathrm{C} 00 \mathrm{H} 13$

Yamada Y, Fukuda H, Inoue K, Kogure K, Nagata T (2013) Effects of attached bacteria on organic aggregate settling velocity in seawater. Aquat Microb Ecol 70:261-272

Yamada Y, Fukuda H, Uchimiya M, Motegi C, Nishino S,

Editorial responsibility: Ronald Kiene,

Mobile, Alabama, USA
Kikuchi T, Nagata T (2015) Localized accumulation and a shelf-basin gradient of particles in the Chukchi Sea and Canada Basin, western Arctic. J Geophys Res Oceans 120:4638-4653

Yamamuro M, Kayanne H (1995) Rapid direct determination of organic-carbon and nitrogen in carbonate-bearing sediments with a Yanaco Mt-5 Chn analyzer. Limnol Oceanogr 40:1001-1005

Y Yang Y, Motegi C, Yokokawa T, Nagata T (2010) Largescale distribution patterns of virioplankton in the upper ocean. Aquat Microb Ecol 60:233-246

Submitted: March 16, 2017; Accepted: September 14, 2017

Proofs received from author(s): November 8, 2017 